\title{
The Origins of Technology-Skill Complementarity
}

\section{Citation}

Goldin, C., and L. F. Katz. 1998. "The Origins of Technology-Skill Complementarity." The Quarterly Journal of Economics 113 (3) (August 1): 693-732. doi:10.1162/003355398555720.

\section{Published Version}

$10.1162 / 003355398555720$

\section{Permanent link}

http://nrs.harvard.edu/urn-3:HUL.InstRepos:27867130

\section{Terms of Use}

This article was downloaded from Harvard University's DASH repository, and is made available under the terms and conditions applicable to Other Posted Material, as set forth at http:// nrs.harvard.edu/urn-3:HUL.InstRepos:dash.current.terms-of-use\#LAA

\section{Share Your Story}

The Harvard community has made this article openly available.

Please share how this access benefits you. Submit a story.

Accessibility 


\title{
THE ORIGINS OF TECHNOLOGY-SKILL COMPLEMENTARITY
}

\author{
Claudia Goldin \\ Lawrence F. Katz
}

NBER Working Paper 5657

\author{
NATIONAL BUREAU OF ECONOMIC RESEARCH \\ 1050 Massachusetts Avenue \\ Cambridge, MA 02138 \\ July 1996
}

A shorter version of an earlier draft of this paper was presented at the AEA Session on Technology, Human Capital, and the Wage Structure, January 1996, San Francisco, CA, and will appear in the American Economic Review, Papers and Proceedings, (May 1996) as "Technology, Skill, and the Wage Structure: Insights from the Past." Steve Allen was the discussant and we thank him for his comments.

Arthur Woolf generously provided us with his sample of 4-digit SIC-code manufacturing data for 1909 to 1929. Seminar participants at Harvard University, Johns Hopkins University, M.I.T., Cornell University, UCLA, the University of Chicago, and Northwestern University offered useful advice. The critical comments of John Dunlop, Edward Glaeser, and Andrei Shleifer have made this a better paper, although it will be obvious to them that we have not yet been able to implement all of their suggestions. Bridget Chen and Mireille Jacobson provided research assistance. We thank all those mentioned. This paper is part of NBER's research programs in the Development of the American Economy, and Labor Studies. Any opinions expressed are those of the authors and not those of the National Bureau of Economic Research.

(C) 1996 by Claudia Goldin and Lawrence F. Katz. All rights reserved. Short sections of text, not to exceed two paragraphs, may be quoted without explicit permission provided that full credit, including $(\mathcal{C}$ notice, is given to the source. 


\title{
THE ORIGINS OF TECHNOLOGY-SKILL COMPLEMENTARITY
}

\begin{abstract}
Current concern with relationships among particular technologies, capital, and the wage structure motivates this study of the origins of technology-skill complementarity in manufacturing. We offer evidence of the existence of technology-skill and capital-skill (relative) complementarities from 1909 to 1929, and suggest that they were associated with continuous-process and batch methods and the adoption of electric motors. Industries that used more capital per worker and a greater proportion of their horsepower in the form of purchased electricity employed relatively more educated blue-collar workers in 1940 and paid their blue-collar workers substantially more from 1909 to 1929 . We also infer capital-skill complementarity using the wage-bill for non-production workers and find that the relationship was as large from 1909-19 as it has been recently. Finally, we link our findings to those on the high-school movement (1910 to 1940). The rapid increase in the supply of skills from 1910 to 1940 may have prevented rising inequality with technological change.
\end{abstract}

Claudia Goldin

Department of Economics

Harvard University

Cambridge, MA 02138

and NBER
Lawrence F. Katz

Department of Economics

Harvard University

Cambridge, MA 02138

and NBER 
The recent coincidence of computerization and a widening wage structure has led many to conclude that new technologies and human capital are relative complements (e.g., Bound and Johnson 1992). A related literature has demonstrated that physical capital and skill are relative complements today and in the recent past. ${ }^{1}$ Thus capital deepening may also have increased the relative demand for the educated, serving further to stretch the wage structure. According to this view, only large injections of education can reduce the impact of technology on inequality. ${ }^{2}$ The possibility that such a relationship exists today has prompted a widely-noted conjecture that technological progress and skill have always been relative complements. ${ }^{3}$

Physical capital and more advanced technology are now regarded as the relative complements of human capital, but have they been so for the past two centuries? Some answers have already been provided. A literature on the bias to technological change across history challenges the view that physical and human capital were relative complements throughout the

\footnotetext{
${ }^{1}$ The empirical research covering the post-World War II period, beginning with Griliches (1969) and summarized by Hamermesh (1993), supports the capital-skill and technology-skill complementarity hypotheses. Bartel and Lichtenberg (1987) find, from a panel of manufacturing industries from 1960 to 1980 , that the implementation of new technologies, proxied by the age of the capital stock, increases the share of highly-educated labor in total labor cost. Doms, Dunne, and Troske (1995) show that U.S. manufacturing plants utilizing more-advanced technologies employ more educated workers. Berman, Bound, and Griliches (1994) conclude that skill-upgrading across U.S. manufacturing industries during the last thirty years is positively associated with the rate of growth of the capital-output ratio and with the level of investment in R\&D and computers. Berndt, Morrison, and Rosenblum (1992) reach a similar conclusion. Autor, Katz, and Krueger (1996) find a substantial and growing wage premium associated with computer use despite large increases in the supply of workers with computer skills. They also find greater shifts towards college-educated workers in industries with more rapid growth in employee computer usage (see also Krueger 1993). Fallon and Layard (1975) confirm the capital-skill complementarity hypothesis using cross-country data at both the aggregate and sectoral levels. Positive correlations have also been found between the utilization of formal company training, and technological change and sectoral capital intensity (Bartel and Sicherman 1995; Mincer 1989).

${ }^{2}$ Tinbergen (1975), for example, has characterized the evolution of the wage structure as a "race between technological development and access to education." Direct intervention in wage setting, of course, can also alter the wage structrue.

${ }^{3}$ By skill we mean higher levels of education, ability, or job training. When we use the term technology-skill or capital-skill complementarity we mean that skilled or more educated labor is more complementary with new technology or physical capital than is unskilled or less educated labor.
} 
industrial past. Many of the major technological advances of the nineteenth century, according to the more recent literature, substituted physical capital, raw materials, and unskilled labor, as a group, for highly-skilled artisans. ${ }^{4}$ Rather than being the relative complement to human skill, physical capital was, for some time, a relative complement of raw materials and together, with unskilled labor, substituted for highly-skilled individuals (Cain and Paterson 1986; James and Skinner 1985). ${ }^{5}$ The prototypical example is that of the gunmaker. Cheap raw materials in America fostered the use of wood lathes and displaced hand fitting in the production of gun stocks by skilled woodworkers (Hounshell 1984). Similarly, the cordwainer once made shoes by hand with practically no physical capital. The intricate division of labor of the shoe factory began, and its later mechanization completed, the transition from artisan to unskilled operative. ${ }^{6}$ The butcher, baker, smith, and glass blower were also skilled artisans whose occupations were profoundly altered by the factory system, capital, and mechanization. ${ }^{7}$

If, as the literature now claims, technological advance and human skill were not always

\footnotetext{
${ }^{4}$ Throughout this paper we use the term artisan to mean a worker who produces virtually the entire good.

${ }^{5}$ James and Skinner (1985) divide industries in 1850 into two categories: "skilled" (e.g., woodworking) and "unskilled" (e.g., clothing). They find that in both "skilled" and "unskilled" industries raw materials were the relative complements of physical capital, although the effect was greater in the "skilled" sector. More importantly for the capital-skill complementarity hypothesis is that skilled labor was the better substitute for capital in its sector than was unskilled labor in its. Thus an increase in capital (or raw materials) would have decreased the relative demand for skilled labor. Cain and Paterson (1986) do not consider skill differences but find, similar to James and Skinner, that capital and raw materials were relative complements and that both together substituted for labor.

In the framework we provide below, capital and skilled labor are complements in the creation of workable machinery which is then used together with unskilled labor to produce output. We use, here, the language of the existing literature rather than that of our framework.

${ }^{6}$ According to Sokoloff (1986) the initial deskilling involved little capital and mechanization and was of the Smithian pin-factory variety. Landes (1972) takes an opposing view.

${ }^{7}$ Braverman (1974), among others, argues that industrialization and mechanization served to deskill a host of artisanal trades and reduce the relative earnings of craftsmen. Yet Williamson and Lindert (1980), in their innovative book on historical trends in inequality, rely heavily on capital-skill complementarity to generate, in their C.G.E. model, rising inequality with economic development during the nineteenth century.
} 
relative complements, when did they become so? We argue that technology-skill and capitalskill complementarity emerged across the manufacturing sector as particular technologies, known as batch and continuous-process methods of production, spread. ${ }^{8}$ Reinforcing the trend was another technological change: the switch to purchased electricity from steam and water-power energy sources.

Our interest, like that of many we cite, concerns how technological change affects the relative demand for skills. Because technological change is often accompanied by increases in capital intensity, capital has often been the focus. But many major advances are associated with particular types of capital, like computers are today and electric motors were in the past. As our measure of technological change we will often use capital intensity, although we also consider electricity use and particular types of production processes.

Manufacturing production shifted, during the past 150 years, from artisanal shops to factories (1830s to 1880s) and later assembly-lines (early 1900s), then from factories to continuous and batch processes (1890s and beyond), and more recently to robotized assembly lines. The technological shifts did not affect all products the same, and some were never manufactured by more than one of the technologies. But manufacturing, as a whole, progressed in this fashion. ${ }^{9}$

\footnotetext{
${ }^{8}$ Batch methods were common to various production processes such as those in chemicals, certain nonferrous products, some foods (e.g., butter, sugar), liquors, beer, and a host of other products that are liquid. Late in the nineteenth century and continuing to ours, continuous-process methods were pioneered in products requiring little assembly and having few or no moving parts, such as oats, flour, canned foods (e.g., condensed milk, soup), soap, film, paper, matches, and cigarettes (Chandler 1977).

${ }^{9}$ See, for example, Atack (1987) and Sokoloff (1984) concerning the transition from the artisanal shop to the factory in the nineteenth century. Both make the important point that the transition was slow in some industries. It depended not just on technological change (often simply changes in the organization of work) but also on decreases in transport costs. In some industries (e.g., boots and shoes, clothing, furniture, leather, meatpacking, tobacco) a significant minority of value added was produced in artisanal shops ( $<7$ employees with no power source) even as late as 1870 . And in some (e.g., saddlery), the majority of value added came from artisanal shops in 1870 . Even though there were economies from larger scale for much of manufacturing, transport costs were still too high to justify a complete shift in the mode of production across the entire United States.
} 
Even though the transition from the artisanal shop to the factory may have increased the capital-output ratio, it most likely decreased the overall demand for skilled relative to unskilled labor. The technological advances that prompted the shift from the factory to continuous-process methods increased the relative demand for skilled labor while increasing the capital-output ratio. Thus the shift from the factory to continuous-process or batch methods may have produced manufacturing-wide capital-skill (technology-skill) complementarity. Electrification and the adoption of unit-drive machines reinforced the change through the automation of hauling and conveying operations. ${ }^{10}$

Few products went through all the stages we describe, but those that did provide illuminating examples. Automobile production began in large artisanal shops. Like the carriages that preceded them, automobiles were assembled by groups of artisans who hand-fitted the various pieces. ${ }^{11}$ Technological advances led to standardized and completely interchangeable parts that were then assembled in factories by scores of less-skilled workers, while skilled craftsmen constructed, installed, and maintained the machines. It was only a matter of time for the assembly line to be innovated, as it was at Ford in 1913. Much later, the robotized assembly line was created using relatively fewer less-skilled operatives and more skilled machinecrewmen. In the history of automobile production, the first technological advances reduced the relative demand for skilled labor but later advances increased it.

We explore the transition to technology-skill complementarity, believed to be in full blossom today. Our central point is that the shift to batch and continuous- process methods, as well as the rise in purchased electricity, led to an increase in the relative demand for higher-

\footnotetext{
${ }^{10}$ Jerome (1934) illustrates this point for many industries.

${ }^{11}$ Braverman (1974) quotes Eli Chinoy: "Final assembly, for example, had originally been a highly skilled job. Each car was put together in one spot by a number of all-around mechanics" (p. 146). See also Hounshell (1984).
} 
skilled and educated workers. Reinforcing the shift in manufacturing was an increased demand for educated labor to sell, install, and service technologically-advanced products. ${ }^{12}$

\section{A Framework to Understand Capital-Skill and Technology-Skill Complementarity}

In considering our argument, it is useful to envision manufacturing as having two distinct stages: a machine-installation, machine-maintenance segment (termed "capital-maintenance") and a production or assembly portion (termed "production"). The two stages together comprise "manufacturing." Capital and educated (skilled) labor, we will argue, are always complements in the machine-maintenance segment of manufacturing for any technology. Machinists, for example, are needed to install machinery and make it run. ${ }^{13}$ The "workable" capital created by skilled labor and raw capital is then used by unskilled labor to create the final product in the production or assembly segment of manufacturing.

The adoption of a particular technology may increase or decrease the capital to output ratio. Whether or not its adoption increases or decreases the relative demand for skilled workers will generally depend on the degree to which the machine-maintenance portion's demand for skilled labor is offset by the production process's demand for unskilled labor. We outline a more

\footnotetext{
${ }^{12}$ In the past ten years individuals who sell computer software and hardware have changed from nerds to slick sales personnel. Similarly, in the 1920s those who sold radios had to deal with the "radio nuts," as they were called, but not much later, radio sales personnel were hired to increase sales, not fraternize with the wireless amateurs. We do not, in this paper, consider the impact technology had on skill demands in other than the manufacturing sector.

${ }^{13}$ Machine-maintenance, however, may itself have a life-cycle, particularly for the factory or assemblyline technology: "In the first stages of such mechanization when machines are somewhat crude, their operation requires the watchful care of skilled machinists. Likewise, to make those improvements which increase machine efficiency, competent machinists are employed to observe the machines in operation under practical working conditions. But, as machines increase in importance, they must be further improved in efficiency so as to require little attention and a minimum number of stoppages for repairs or overhauling. This increasing efficiency of the machine itself tends, in the long run, to eliminate much of the work of that large corps of machinists which was required when machines were first installed to displace handworkers" (Anderson and Davidson 1940, p. 228).
} 
formal framework showing that the immediate effects of the shift from the artisanal shop to the factory were probably an increase in the capital-output ratio and a decrease in the demand for skilled relative to unskilled labor. The shift from the factory to continuous-process (or batch) methods, however, raised the capital-output ratio but increased the relative demand for skilled labor. Within any of the technologies, however, an increase in the ratio of the unskilled to skilled wage will induce an increase in the capital-output ratio, the capital-labor ratio, and the relative demand for skilled labor. That is, we hypothesize that capital and skill are always relative complements within any technology. But we believe that shifts in technology, rather than changes in relative factor prices, have been more important across history in altering capital-output and capital-labor ratios.

Our framework posits three types of technologies (and one that has two phases): artisanal shop or hand production $(\mathrm{H})$, the factory $(\mathrm{F})$ which in its more technologically-advanced stage is called the assembly line (A), and a continuous-process or batch (C) technology. There are three inputs: raw capital $(K)$, skilled or educated labor $\left(L_{s}\right)$, and unskilled labor $\left(L_{u}\right)$, with corresponding prices $r, w_{s}$ and $w_{u}$. The manufacturing process contains two distinct portions: (1) raw capital must be installed and, later, serviced ("capital maintenance") and (2) goods must be assembled or created ("production"). All workers in the "production" segment are unskilled, whereas all workers in the "capital-maintenance" portion are skilled.

The "capital maintenance" portion of manufacturing is Leontief and, thus, physical capital and human capital are always strictly complements in the creation of usable, workable capital for all technologies. We will label the usable, workable capital as $\mathrm{K}^{*} \cdot{ }^{14}$ The production portion of manufacturing uses $\mathrm{K}^{*}$ and $\mathrm{L}_{\mathbf{u}}$ to manufacture $\mathrm{Q}$ and is Cobb-Douglas. Thus the creation of $\mathrm{K}^{*}$

\footnotetext{
${ }^{14}$ We also assume, realistically, that $\mathrm{K}^{*}$ cannot be shifted about from one technology to another but is specific to the technology for which it was created.
} 
is a separable part of the production of $\mathrm{Q}^{15}$

The same factor proportions are needed to create $\mathrm{K}^{*}$ in the $\mathrm{F}$ (or $\mathrm{A}$ ) and $\mathrm{C}$ technologies, but the $\mathrm{H}$ technology requires a larger amount of $\mathrm{L}_{s}$ relative to $\mathrm{K}$ (see Figure 1, part $\mathrm{A}$ ). In the production of $Q$, however, the $H, F$ (or $A$ ), and $C$ production functions differ in factor intensity (see Figure 1, Part B). Production of $Q$ using the $H$ technology is the most intensive in $K^{*}$, next is $\mathrm{C}$, and last is $\mathrm{F}$ (or A). That is, artisanal or hand production has the highest skilled-labor to capital ratio, relative to the other production methods, in the creation of workable capital. And when its workable capital is used in the production process it has the greatest output elasticity. The factory and continuous-process technologies require a higher capital to skilled labor ratio in the creation of workable capital, but both have a lower output elasticity for workable capital in the production process than does the artisanal shop, the factory system having the lowest. More formally, we assume that $\mathrm{K}^{*}$ is generated by:

$$
\mathrm{K}^{*}=\min \left(\lambda_{\mathrm{i}}^{1} \cdot \mathrm{L}_{s}, \lambda_{\mathrm{i}}^{\mathbf{k}} \cdot \mathrm{K}\right) \quad \mathrm{i}=\mathrm{H}, \mathrm{F}, \mathrm{A}, \mathrm{C}
$$

such that $\lambda_{F, A, C}^{1}>\lambda_{H}^{1}$ and $\lambda_{F, A, C}^{k}<\lambda_{H}^{k}$, where $1 / \lambda^{1}{ }_{i}$, for example, is the unit skilled-labor requirement for $\mathrm{K}^{*}$ creation in production process i. Q production is, likewise, given by:

$$
\mathrm{Q}=\gamma_{\mathrm{i}} \cdot\left(\mathrm{L}_{\mathrm{u}}\right)^{\alpha_{\mathrm{i}}}\left(\mathrm{K}^{*}\right)\left(1-\alpha_{\mathrm{i}}\right) \quad \mathrm{i}=\mathrm{H}, \mathrm{F}, \mathrm{A}, \mathrm{C}
$$

such that $\alpha_{\mathrm{H}}<\alpha_{\mathrm{C}}<\alpha_{\mathrm{F}, \mathrm{A}}$.

Even though skilled labor and capital are strictly complements in capital-maintenance for all technologies, as in eq. (1), capital-skill complementarity need not be observed for

\footnotetext{
${ }^{15}$ Our framework produces results that are qualitatively similar to those of a more general production function such as a two-level CES of the form:

$$
\begin{array}{ll}
\mathrm{Q}=\mathrm{A}_{\mathrm{i}}\left[\alpha_{\mathrm{i}}\left(\mathrm{K}^{*}\right)^{\rho_{\mathrm{i}}}+\left(1-\alpha_{\mathrm{i}}\right) \mathrm{L}_{\mathrm{u}}^{\rho_{\mathrm{i}}}\right]^{1 / \rho_{\mathrm{i}}} & \rho_{\mathrm{i}} \leq 1 \\
\mathrm{~K}^{*}=\left[\begin{array}{lll}
\beta_{\mathrm{i}}(\mathrm{K})^{\theta_{\mathrm{i}}}+\left(1-\beta_{\mathrm{i}}\right) & \mathrm{L}_{\mathrm{s}}^{\theta_{\mathrm{i}}}
\end{array}\right]^{1 / \theta_{\mathrm{i}}} & \theta_{\mathrm{i}} \leq 1
\end{array}
$$

as long as $\rho_{\mathrm{i}}>\theta_{\mathrm{i}}$ for all $i$. We analyze the special case for which $\rho_{\mathrm{i}}=0$ and $\theta_{\mathrm{i}}=-\infty$.
} 
manufacturing as a whole as technology advances (by which we mean a movement from artisanal production to the factory and eventually to continuous-process methods). ${ }^{16}$ The reason can be seen with reference to Figure 1 (see also Table 1). Part B of Figure 1 is drawn so that all isoquants represent equal amounts of $Q$. It has also been drawn for a very special case of $K^{*}$ production, one in which the average cost of $\mathrm{K}^{*}$ for all technologies is the same (and thus for which the isocost lines in Part B are parallel). If $r^{*}$ is the average cost of $K^{*}$ for technology $i$, the condition for which $\mathrm{r}^{*}$ is equal for the $\mathrm{H}$ and $\mathrm{F}$ (or $\mathrm{A}$ or $\mathrm{C}$ ) technologies is:

$$
r / w^{s}=\left[\left(\lambda_{F}^{1}\right)^{-1}-\left(\lambda_{H}^{1}\right)^{-1}\right] /\left[\left(\lambda_{H}^{k}\right)^{-1}-\left(\lambda_{F}^{k}\right)^{-1}\right]
$$

The condition, although not necessary, makes the geometry far simpler. ${ }^{17}$ Without it, however, we will need another, less restrictive, condition for one of the results.

Initially, say in time period 0 , consider the factory system to be in its infancy, continuous processes have not yet been invented, and the artisanal shop is the dominant mode of production. We begin, therefore, at point $\mathrm{H}_{0}$. Note that just because $\mathrm{K}^{*}$ is relatively high does not mean that much raw capital per unit of output is used. As can be seen in Part A of Figure 1, the $\mathrm{H}$ technology uses relatively more $\mathrm{L}_{s}$ than do the other technologies in producing $\mathrm{K}^{*}$.

Technological change eventually makes the factory system the dominant mode of $Q$ production, as can be seen by the Hicks-neutral technical change from $F_{0}$ to $F_{1}$ (resulting from an increase in $\gamma_{\mathrm{F}}$ ). As this type of technological change proceeds, firms will eventually switch from the $\mathrm{H}$ to the $\mathrm{F}$ technology (just beyond $\mathrm{F}_{1}$ in Figure 1, Part B). The shift from artisanal shops to factories initially causes an increase in $(\mathrm{K} / \mathrm{Q})$, in $\left(\mathrm{K} / \mathrm{L}_{\mathrm{s}}\right)$, probably also in $\mathrm{K} /\left(\mathrm{L}_{\mathrm{s}}+\mathrm{L}_{\mathrm{u}}\right)$,

\footnotetext{
${ }^{16}$ By a technological advance from artisanal production to the factory system we mean an increase in $\gamma_{\mathrm{F}}$ relative to $\gamma_{\mathrm{H}}$. The appearance of continuous or batch processes, likewise, comes from an increase in $\gamma_{C}$ relative to $\gamma_{F}$.

${ }^{17}$ If the $\mathrm{r}^{*} \mathrm{~s}$ were different, the isocost lines would not be parallel. The condition simply states that the degree to which the cost of a unit of $\mathrm{K}$ exceeds that for a unit of $\mathrm{L}_{s}$ must equal the degree to which $F$ conserves on $L_{s}$, relative to $H$, compared with how much $H$ conserves on $K$, relative to $F$.
} 
and, most importantly, a decrease in $\mathrm{L}_{s} /\left(\mathrm{L}_{\mathrm{s}}+\mathrm{L}_{\mathrm{u}}\right) \cdot{ }^{18}$ In the more general case of our framework, in which the isocost lines in Part B are not parallel for the $\mathrm{H}$ and $\mathrm{F}$ technologies, a weaker condition than that given by eq. (3) is required for an increase in the relative demand for unskilled labor to emerge from the shift to the factory. The condition requires that the share of unskilled labor in total product for the factory technology be sufficiently larger than the share for the artisanal shop technology. It is likely that such a condition held. ${ }^{19}$

Additional Hicks-neutral technical change shifts the $\mathrm{F}$ isoquant to A, possibly through an organizational innovation: the assembly line. The shift does not change the capital-labor ratio, nor the relative demand for skilled labor, but it does lower the capital-output ratio.

The shift of most interest to us is the appearance of another technology, that of continuous-process methods, given by isoquant $\mathrm{C}^{20}$ Although its capital maintenance technology is identical to that of the $A$ or $F$ processes, it has a higher output elasticity with respect to $K^{*}$ than do the $A$ or $F$ processes $\left(\alpha_{C}<\alpha_{F, A}\right)$. Its eventual adoption will increase $(K / Q), K /\left(L_{s}+L_{u}\right)$, and $\mathrm{L}_{\mathrm{s}} /\left(\mathrm{L}_{\mathrm{s}}+\mathrm{L}_{\mathrm{u}}\right)$. That is, with its adoption we will observe capital-skill complementarity and

\footnotetext{
${ }^{18}$ See Table 1 for the various conditions. We are considering here a small factor-neutral technological change around $F_{1}$. Greater technological change, as in the movement to $A$, can decrease $K / Q$.

${ }^{19}$ More formally, the condition is that: $\left(\mathrm{r}_{\mathrm{H}}^{*} / \mathrm{r}_{\mathrm{F}}^{*}\right)<\left[\left(\alpha_{\mathrm{F}} / \alpha_{\mathrm{H}}\right)\right] \cdot\left[\left(1-\alpha_{\mathrm{H}}\right) /\left(1-\alpha_{\mathrm{F}}\right)\right] \cdot\left(\lambda_{\mathrm{F}}^{1} / \lambda_{\mathrm{H}}^{1}\right)$. Intuitively, the condition for the shift from $\mathrm{H}$ to $\mathrm{F}$ to decrease the relative demand for skilled labor, given $\mathrm{Q}$, will not occur if $\left(\mathrm{r}_{\mathrm{H}}^{*} / \mathrm{r}_{\mathrm{F}}^{*}\right)$ is too high. The cost of installed capital will be relatively high in the $\mathrm{H}$ sector when the cost of skilled labor is great in comparison with raw capital. When that occurs, the $\mathrm{H}$ sector will have an incentive to conserve on expensive $K^{*}$ in the production of $Q$, thus substituting unskilled labor for $K^{*}$. But the condition will hold, even when $\left(r_{H}^{*} / r_{F}^{*}\right)$ is high, if $\alpha_{H}$ is sufficiently low in comparison with $\alpha_{F}$. The shift to the $\mathrm{F}$ technology will, then, still increase the relative demand for unskilled labor because the marginal product of $L_{u}$ is lower in the $H$ technology (given $Q$ and $L_{u}$ ). The effect is further helped by the assumption that $\lambda_{F}^{1}>\lambda_{H}^{1}$. It does seem reasonable that, for given $Q$ and $L_{u}$, the marginal product of unskilled labor was lower in the artisanal shop mode of production compared with the factory. After all, the reason for having the factory system, with its more intricate division of labor, was to increase the marginal product of unskilled labor.

${ }^{20}$ The shift from $A$ to $C$ could arise from exogenous technological advance (growth in $\gamma_{C}$ relative to $\gamma_{\mathrm{A}, \mathrm{F}}$ ) or such change could have been fostered by an increase in the relative price of unskilled labor (increase in $w_{u} / r^{*}$ ), as may have occurred with the expansion of high schools after c.1910 and with the ending of open immigration in the 1920s.
} 
technology-skill complementarity, at given factor prices. ${ }^{21}$

Note that the introduction of electricity and unit-drive in many factories had effects similar to those arising from a shift to continuous-process technology. The mechanization of the hauling and conveying of materials decreased the relative demand for unskilled labor, and the faster and hotter running of machinery required relatively more machine-maintenance personnel.

\section{Technology-Skill and Capital-Skill Complementarity: 1909 to 1940}

We turn now to the historical record to observe when capital and skill, or technology and skill, became relative complements. Because capital is more easily measured than technology and its use facilitates comparisons with the more recent period, we will often focus on capitalskill complementarity. But we are also able to gauge technological advance in the past by the use of purchased electricity. The U.S. censuses of manufactures for 1909 and 1919 contain information on the capital stock, but that for 1929, important in our measure of technology by purchased electricity use, does not. Employment is not disaggregated into subgroups of bluecollar workers, except by sex and by child versus adult. ${ }^{22}$ And we do not have direct evidence on the average skill or education of workers in those years, although white-collar workers were

${ }^{21}$ Although we do not have a fourth input -- raw materials -- it is easy to compare our framework with that in James and Skinner (1984). Their skilled sector is our artisanal sector, and it shifts from the $\mathrm{H}$ to the $\mathrm{F}$ technology, thereby increasing $\mathrm{K} / \mathrm{Q}$, probably also $\mathrm{K} / \mathrm{L}$, but decreasing the fraction of the work force that is skilled. The cause of the technological shift in their case is the lower relative price of raw materials in the United States versus Britain.

${ }^{22}$ Capital was also inquired of in 1914, but the question on the capital stock ended in 1919. In 1939 a question was asked on capital investment. For a discussion of the accuracy and consistency of the capital stock variable and for its defense, see Creamer et al. (1960, appendix A). Capital was to include only the owned portions of land, buildings, machinery, tools, inventories, and working capital (e.g, cash) and to be assessed at book value. 
grouped separately. ${ }^{23}$ Beginning in 1940 the U.S. census of population asked information on highest grade completed, industry, and occupation. Using all these sources, and the narrative historical record, we explore the origins of capital-skill and technology-skill complementarity. ${ }^{24}$

The 1940 census allows us to identify industries that used disproportionate numbers of higher-educated (e.g., high-school graduate) workers in blue-collar occupations, and the census of manufactures can reveal whether "high-education" industries were more capital- or electricityintensive from 1909 to 1929 . We find, looking across narrowly-defined industries in 1909 and 1919, that "high-education" industries, categorized on the basis of 1940 data, were both more capital- and electricity-intensive. They also paid their production workers more in 1909, 1919, and 1929, suggesting that these workers were more skilled in the 1910s and 1920s.

Many of the industries we characterize as capital-intensive and "high-education" have been classified by others (e.g., Chandler 1977) as using continuous-process or batch technologies. The evidence for the 1909 to 1929 period is consistent with the notion that the transition from the factory (or assembly-line) to these processes increased the relative demand for skilled workers and thus can be viewed as a candidate for the origins of economy-wide capital-skill complementarity. The previous transition, from the artisanal shop to the factory, involved just the opposite force. Many of the industries that remained craft in nature (e.g., engraving, jewelry,

\footnotetext{
${ }^{23}$ The groups were proprietors and firm members; salaried officers of corporations; superintendents managers, engineers, and other technical experts; and clerks, stenographers, salesmen, and other salaried employees.

${ }^{24}$ Several data sets culled from the U.S. censuses of manufactures are used. We assembled data for 1909 and 1919 and matched them by (pseudo) 4-digit SIC industry using the 1909 industries. Similar data, covering 1909, 1914, 1919, and 1929, were generously provided by Arthur Woolf (see Woolf 1980). They contain information on power sources, omit some detail on wage-earners, and are not matched over time by industry. We matched the 1929 industries in the Woolf data to our 1909 and 1919 industries and added the missing information on wage-earners. Across the three years $(1909,1919$, and 1929) we can match 228 (pseudo) 4-digit industries covering 99\% of employment in those years. The 1909 and 1919 census data surveyed all firms with more than $\$ 500$ in gross output; that for 1929 used a $\$ 5000$ cutoff point. There appear to be no important biases as a result (see Fabricant 1940).
} 
clocks and watches) had far lower capital intensity but higher skill (education) per worker than did the majority of the industries that shifted to factory-style production techniques.

Capital and skill, measured by the utilization of non-production workers, appear complementary across manufacturing. We find for 1909-19, using a methodology similar to that in Berman, Bound, and Griliches (1994), that the change in the proportion of an industry's wage bill going to white-collar workers was positively related to the change in both capital-intensity and purchased electricity. And the coefficient measuring capital-skill complementarity for 190919 is larger than for 1959-69 and 1969-79 and almost as great as that for 1979-89.

\section{Educated Labor in Blue-Collar Occupations}

The 1940 U.S. census of population contains the earliest evidence regarding the educational attainment of American workers by industry and occupation. ${ }^{25}$ Using these data, we explore whether the blue-collar labor force varied in its schooling by industry. We limit the analysis of the 1940 data to males, 18 to 34 -years old in blue-collar occupations (craft, operatives, laborers, service) working in the manufacturing sector. ${ }^{26}$ The age limitation is imposed because the educational attainment reported by older Americans in the 1940 census appears overstated (Goldin and Katz 1996). Secondary schooling, moreover, increased greatly in the 1920s and 1930s, and thus the educations of older Americans would have been largely untouched by these changes. We first restrict the analysis to blue-collar occupations because questions concerning capital-skill complementarity often revolve around the skill content of production workers.

\footnotetext{
${ }^{25}$ The 1940 U.S. population census was the first to ask the educational attainment. Only three state censuses did so prior to 1940 (Iowa 1915, 1925; South Dakota 1915). Small samples exist that contain data on education and occupation, and the 1934-36 Consumer Expenditure Survey does as well. But none is national in scope, unbiased in the population sampled, and large, with the possible exception of the lowa data which we are currently collecting.

${ }^{26}$ Our substantive findings are very similar if we look, instead, at the educational attainment of all male workers or at all blue-collar workers, rather than restrict attention, as we do, to 18 to 34 year old blue-collar males.
} 
Among all 18 to 34-year old, male blue-collar manufacturing workers in the 1940 PUMS (Public Use Microdata Sample), 27.4\% stated they completed 12 years of schooling and most of them were probably graduates of high schools. ${ }^{27}$ As a fraction of the total blue-collar work force, the more educated were disproportionately found in certain industries. The industries, moreover, fit the categorization we offered previously, for many were continuous-process and batch technologies (petroleum refining, dairy products, paints and varnishes, nonferrous metals) or were high-technology industries and those producing relatively new goods (aircraft, business machinery, scientific and photographic equipment). ${ }^{28}$

We list, in Table 2, industries by the percentage of their blue-collar male workers (18 to 34 years old) who were high-school graduates, giving those in the top and bottom $20 \%$ by employment. $^{29}$ The industries divide into two categories. At the low end of the education spectrum are the products of the first industrial revolution and those of construction: cotton, woolen, and silk textiles, boots and shoes, lumber, stone, clay, and cement. At the other end are the newer goods and services of the second industrial revolution (e.g., chemicals, petroleum), as well as many in the machine-producing group. Also in this category are some that were produced in settings similar to the artisanal shop: clocks, watches, jewelry, and even aircraft.

${ }^{27}$ The sample is restricted to the currently-employed. In 1940 more than $10 \%$ of those in the labor force were unemployed and an additional $4 \%$ were on work-relief. Most, rather than all, of those who claimed to complete 12 years of school graduated from high school because, even as late as 1940, some had been educated in ungraded schools, some may have been left back in school, and some, in this period of soaring education levels, may have overstated their school attainment, as we believe was the case for older cohorts (see Goldin and Katz 1995a).

${ }^{28}$ The list would probably include many others in the batch and continuous-process group if the 1940 census tabulated finer categories of industries, e.g., distilled liquors, pharmaceuticals. Industries are defined as high-technology if a large percentage of their total labor force were engineers, chemists, and other scientific personnel, similar to currently used definitions.

${ }^{29}$ The PUMS gives all 3-digit industries and some of the larger 4-digit ones. In the sectors we analyze there were 61 separate industrial categories (omitting miscellaneous). 
Finally, there is that perennial among high-education industries: printing and publishing. ${ }^{30}$

Before making further sense of the findings regarding high and low-education industries, we must address whether the results have been generated simply by geographic differences in both education and industry or by age differences in employment and educational attainment. Also of interest is whether particular occupations determine the groupings. If, for example, only machinists, a highly educated group, work in aircraft, then aircraft will be a high-education industry. We have regressed the percentage high school on a full set of age, state, and occupation (craft, operative, laborer, service) dummies and find that the residuals by industry retain an almost identical ranking to that of the original data. That is, state of current residence, age, and occupation do not have major effects on the educational ranking of the industry. Even though, for example, aircraft was located in high-education states and employed large numbers of machinists, its other blue-collar workers were also more highly educated and aircraft employed disproportionately more high-education workers even in lower-education states.

Another possibility is that the distribution of educated workers by industry in 1940 was a product of the depression. Firms that employed high-educated workers, according to this logic, would, in the face of decreased demand, have fired low-educated workers and replaced them temporarily with their higher-skilled employees. Such occupational changes are well documented for the depression years. But we find that even in 1950 and 1960 most of the higheducation industries and sectors we identify in 1940 remain high-educated. Our categorization

\footnotetext{
${ }^{30}$ The results do not differ substantially if we considered years of education instead of the percentage graduating from high school. Although we do not here present evidence for sectors other than manufacturing, they display similar patterns. More educated blue collar workers in the communications, transportation, and public utilities sectors were found in telephone, wire \& radio, air transportation, petroleum \& gasoline pipe lines, electric light \& power, and radio broadcasting \& television. In retail trade new products and those that were time-sensitive or more valuable per unit were sold, delivered, and serviced by high school graduates, For example, drivers for jewelry stores and drug stores were more educated than other drivers. Blue-collar workers in radio stores and even gas-station attendants were far more educated than the average blue-collar worker.
} 
does not appear to be merely a product of the depression.

A related issue is whether firms paid their higher-educated, blue-collar workers more in 1940. We find that the rate of return to a year of education in a standard earnings equation, for male blue-collar workers (white, 18 to 34 -years old), was $8.3 \%{ }^{31}$ The return for an equivalent group of ordinary white-collar workers was $8.9 \%$. Even within the blue-collar group there was a substantial return to education, suggesting that the industrial distribution of workers was not merely a by-product of the depression. Of more importance to us, it suggests that firms valued the education of blue-collar workers.

Certain industries, therefore, employed more highly-educated blue-collar workers in 1940. The industries were apparently technologically advanced, frequently of recent origin, often producing goods previously unknown to consumers, and using technologies characterized by continuous-process or batch methods. ${ }^{32}$ But what do these findings signify for capital-skill complementarity?

To investigate capital-education complementarity in the 1909 to 1940 period, we have merged the education data by industry from the 1940 census with that on industry attributes from the 1909, 1919, and 1929 censuses of manufactures. ${ }^{33}$ The 1940 census categories are considerably broader than are those from the censuses of manufactures, which contain about four times as many industries, and we have aggregated the earlier data to conform to the 1940

\footnotetext{
${ }^{31}$ The coefficient on years of schooling is .083 in a $(\log )$ weekly earnings equation that also includes potential-experience and its square. The return is $7 \%$ with a full set of state dummies (data source is the 1/100, 1940 PUMS).

${ }^{32}$ It should be noted that even though many of the high-education industries were of recent origin, we base our education data only on workers 18 to 34 years old. Differences in the industries could not, therefore, be entirely due to the fact that younger workers were more educated than older workers.

${ }^{33}$ We rely heavily on U.S. Department of Commerce, Bureau of the Census (1940) for the categorization of the 1909 and 1919 industries, but also the insights of Fabricant (1940) concerning products that underwent substantial change.
} 
categories. We regress the educational level of 18 to 34-year old male blue-collar workers in 1940 on the capital to labor ratio (in 1909 and 1919), a measure of electrification (averaged over 1909, 1919, and 1929), and various controls for worker and industry characteristics.

The ratio of capital to wage-earners in 1909 and 1919 is positively related to the education of workers by industry in 1940 (see Table 3, cols. 1, 2). The effect, moreover, is economically significant. Increasing the capital to labor ratio by the equivalent of its difference between the lumber \& timber industry and oleomargarine in 1909 increases the high school graduation rate by 7 percentage points or by $25 \%$ in $1940 .^{34}$ Thus more capital-intensive industries employed a more highly-educated labor force some twenty years later.

We find similar effects with respect to the use of purchased electricity, entered either as the fraction of horsepower that was run by purchased electricity or as the log of the electricity variable per wage earner (cols. 3,4). The effect, moreover, is obtained even when the growth of industry employment from 1909 to 1929 is held constant. Production-worker skill was not simply determined by industry growth and the resulting newness of plant and equipment. Rather, the usage of purchased electricity affected the relative demand for skill independent of industry growth. An 18 percentage point increase in the purchased electricity share of horsepower (a one standard deviation change) is associated with a 3.6 percentage point increase in the share of young blue-collar workers who were high school graduates. Note that increases in total horsepower did not have the same effect. The type of power, not simply the amount, affected the skill level. There are important reasons for this.

Purchased electricity and separate motors enabled many industries to automate conveying

34 (Capital/wage-earners) in lumber \& timber was $\$ 1693$, and was $\$ 5871$ in oleomargarine in 1909. Oleomargarine was produced using a continuous-process technology, whereas lumber \& timber was mainly factory production. The $25 \%$ figure comes from the fact that $27.4 \%$ of all blue-collar males (18 to 34 years old) working in manufacturing were high school graduates in 1940 . 
and hauling operations and thereby eliminate substantial numbers of laborers. Many industries were prompted to introduce these labor-saving methods with the onset of World War I, and chief among them were iron \& steel, brick manufacturing, pottery, Portland cement, pulp \& paper, rubber tires \& tubes, slaughtering \& meat packing, lumber manufacture \& wood-working, and mining (Jerome 1934; Nelson 1987; Nye 1990). ${ }^{35}$ Ample and cheap electricity rendered feasible the production of various materials, such as aluminum and other electrochemicals, that disproportionately used skilled labor. Cheap electricity also encouraged a more intensive use of machines thereby increasing demand for the skilled personnel who maintained them. ${ }^{36}$

Note that we do not mean to imply any direct relationship between the individual workers in 1909 (or 1919) and 1940. In fact, education levels in Table 3 refer to men 18 to 34years old in 1940 who could not possibly have been at work in 1909 . We are claiming, however, that there is something about these industries that increased the value of secondary-school education during the 1909 to 1940 period. Secondary schooling was just beginning to affect the education of the masses in the 1910 s but by the mid-1920s to mid-1930s some $30 \%$ to $50 \%$ of youths, depending on region, had high school diplomas (Goldin 1994). Skilled workers in 1909 and 1919 were probably replaced in subsequent decades by young high-school graduates.

${ }^{35}$ In iron and steel "the proportion of common laborers was cut approximately in half from 1910 to 1931. The evidence is unmistakable," notes Jerome, "that recent progress has eliminated unskilled labor to a much greater extent than other grades" (1934, p. 63). In all these industries, the use of conveyors, travelling cranes, jitneys, carriers, industrial trucks, and other handling devices reduced the relative demand for unskilled labor. The changes, moreover, were evident as early as 1916 to 1920.

${ }^{36}$ The role of electricity in increasing the relative demand for skilled workers is complex. Nye (1990) concludes that electricity increased the relative demand for skill but recognizes the large number of effects. "As the electrified factory evolved it required a different mix of labor and management ... more middle management; more engineers and technicians; fewer artisanal workers; and a more complex grading of worker skills, with many more semiskilled laborers ... and far fewer unskilled workers ... Boy mule drivers in coal mines, carriers in tire factories, or shovelers of raw materials in steel mills saw their work taken over by electric locomotives, conveyors, and cranes ... as a few skilled men using expensive machines did work formerly performed by a mass of the unskilled (pp. 234-35). See also Du Boff (1964) and Devine (1983) on the transition from mechanical to electric drive and the introduction of group and unit drive motors. 
Formal education may have substituted for on-the-job training and formal apprenticeships.

Firms in 1909, 1919, and 1929 also appear to have paid significantly more for educated (skilled) workers. The average blue-collar wage in any of the years is strongly and positively related to the education level of the industry's workers in 1940. The coefficient on years of schooling is $12 \%$ in $1909,10 \%$ in 1919 , and $17.5 \%$ in 1929 , as can be seen in the Table 4 regressions of the (log) average wage on average years of schooling among blue-collar workers. Although it is tempting to interpret the coefficients as rates of return to an individual's education, they are, instead, a combination of that and the return to working in an industry having more educated workers. Using data sets containing more complete information, such as the censuses beginning with 1940 , one can reconstruct the "poorer" data we are forced to use and measure both the individual and industry effects. Almost identical magnitudes are obtained to those we present for 1929 even though the return to an individual's years of education is considerably less. ${ }^{37}$ In light of these comparisons we interpret the coefficients for 1909 to 1929 as indicating that a return to education for blue-collar jobs existed, but that we cannot be certain of its magnitude. ${ }^{38}$

We also analyze, in Table 5, the relationship between average earnings per wage earner

\footnotetext{
${ }^{37}$ We construct a similar regression using micro-level data from the 1940 PUMS by aggregating across industries, The analogous regression of the log(average wage, production workers) by industry on average years of schooling of male blue-collar workers, 18-34 years old, in that industry (and the percentage female of blue-collar workers) yields a coefficient of .185 (s.e. .013). In contrast, a micro-level regression of individual log(earnings) on own schooling (plus a female dummy) yields a coefficient of .040 (s.e. .0004). It should be noted that because an experience variable is not included, the coefficient on education is lower than in regressions to measure the return to education.

${ }^{38}$ The wage regressions in Table 4 (and those in Table 5) use consistent data on average annual earnings of blue-collar workers by industry for 1909, 1919, and 1929. Because hours of work may have varied in a manner that could bias the results, we have also estimated these regressions (for 1909 and 1919) using hourly earnings, where hours worked in each industry is estimated from a distribution of hours. The results are robust to the choice of hourly or annual data.
} 
and the capital and electricity variables in 1909,1919 , and 1929. ${ }^{39}$ We find, consistent with the previous tables, a positive correlation between the capital to labor ratio and wages and, similarly, a positive effect between wages and the percentage of all horsepower coming from electricity. Because World War I caused a transitory compression in production-worker wages, we prefer to concentrate on the 1909 and 1929 coefficients. The magnitudes implied by the coefficients are substantial, particularly with regard to purchased electricity use. The difference, for example, between the capital to labor ratios in the oleomargarine and lumber \& timber industries implies a $5 \%$ premium in wages for oleomargarine; the difference in their purchased electricity use implies a $23 \%$ wage difference. ${ }^{40}$

The wage premia we measure are largely due, we believe, to compositional effects; a greater proportion of more skilled workers were found in industries with more capital per worker and with a greater percentage of industry horsepower coming from purchased electricity. Another interpretation is that the wage differentials reflect premia for identically-skilled individuals working in more capital- and electricity-intensive industries in which there was greater worker bargaining power and managerial discretion (e.g., Slichter 1950). That may well be the case. But the strong correlation between wages in the 1909 to 1929 period and education in 1940 , by industry, convinces us that the compositional effect matters. ${ }^{41}$

That high-school graduate blue-collar workers were employed in particular industries (more capital-intensive ones, those producing newer goods) and were paid substantially more, may come as a surprise to readers of the historical literature on the subject. Rarely is the

\footnotetext{
${ }^{39}$ We use the 1919 capital/labor ratios for 1929.

${ }^{40}$ The wage premia use the 1929 coefficients. The actual difference in wages is $33 \%$. Oleomargarine had a capital to labor ratio in 1919 of $\$ 8759$ and $69.4 \%$ of its horsepower came from purchased electricity; the numbers for lumber \& timber are $\$ 3028$ and $27.5 \%$.

${ }^{41}$ We are currently looking for direct evidence on the matter of skill composition.
} 
education of production workers mentioned. Yet there is narrative evidence, complementing our empirical findings, on the cognitive skills valued in various trades. High-school graduates were sought because they could read manuals and blueprints, knew about chemistry and electricity, could do algebra and solve formulas, and, we surmise, could more effectively converse with nonproduction workers in high-technology industries. ${ }^{42}$ They were hired into particular skilled occupations but also for more ordinary positions in certain "high education" industries.

\section{Capital-Skill Complementarity and Non-Production Workers}

The data for 1909 and 1919 allow another test of the capital-skill complementarity hypothesis, as well as a comparison with more recent estimates, by examining whether the nonproduction worker share of total labor costs increased along with the ratio of capital to output. ${ }^{43}$ The motivation is the notion that the relative size of the non-production worker group captures the average amount of skill required across all workers. More engineers and chemists, according to this logic, necessitate more educated and skilled production workers (see, e.g., Allen 1996). Continuous-process and batch methods according to Chandler (1977) required more managerial and professional employees, relative to production workers, and our estimations above are evidence that such processes also required relatively more skilled blue-collar workers.

42 See, for example, the descriptions of positions in electrical machinery, glass, medicinal manufacturing, paint and varnish, and the printing trades in U.S. Department of Labor (various years, 1918-1921). Those that required some years of high school or a high school diploma commanded general cognitive skills such as "good judgment," "skilled in free-hand drawing," "special ability to interpret drawings," "be familiar with the chemical formulas," "general knowledge of chemicals used," "be able to mix the chemicals." More technical skills were also valued such as "knowledge of electricity" and "of electric wire sizes and insulation," "technical knowledge of the properties of glass," "general knowledge of photography." Printing establishments required that some be "well versed in grammar, spelling, punctuation ... and other essentials of a thorough knowledge of English," and noted that "an elementary knowledge of Latin and Greek is helpful."

${ }^{43}$ Chiswick (1979) addresses a somewhat different question using cross-state aggregate manufacturing data for both 1909 and 1919 and fails to find much evidence of aggregate capital-skill complementarity (where "skilled" workers are salaried officers and managers). Our data are for the same years, but are disaggregated by industry, and we analyze the composition of skill demand within detailed industries. 
The estimating equation comes from a model in which capital, over each ten-year horizon, is considered the quasi-fixed factor and non-production (skilled or educated) and production (unskilled) labor are the variable factors. ${ }^{44}$ If the variable cost function (total labor cost function) for industry $j$ is translog and production exhibits constant returns to scale, then cost minimization produces an equation for the non-production labor share of total labor costs (S) in time $t$ of the form:

$$
S_{j t}=\alpha_{j}+\phi_{j} t+\gamma_{j} \ln \left(w_{n} / w_{p}\right)_{j t}+\rho_{j} \ln (K / Q)_{j t}
$$

where $w_{n}\left(w_{p}\right)$ is the wage of non-production (production) workers, $(K / Q)$ is the capital to output ratio, and $\phi_{j}$ measures the rate of skill-biased technological change in industry $j$. Differencing eq. (4) to eliminate industry fixed-effects, yields the following estimating equation for the change in the non-production share of the wage bill in industry $j$ (under the assumptions that $\gamma_{j}$ and $\rho_{j}$ do not vary across industries or, more realistically, that the average coefficients across industries are being estimated):

$$
d S_{j \mathrm{t}}=\beta_{0}+\beta_{1} \mathrm{dln}\left(w_{\mathrm{n}} / w_{\mathrm{p}}\right)_{\mathrm{jt}}+\beta_{2} \mathrm{~d} \ln (K / Q)_{\mathrm{jt}}+\varepsilon_{\mathrm{jt}}
$$

The coefficient $\beta_{1}$ is greater than or less than 0 depending on whether the elasticity of substitution between non-production and production labor is less than or greater than 1 . The condition $\beta_{2}>0$ implies capital-skill complementarity; $\beta_{0}$ captures the cross-industry average of the skill-bias to technical change and $\left(\beta_{0}+\varepsilon_{\mathrm{j} t}\right)$ is the industry-specific bias to technical change plus measurement error. The intuitive interpretation of $\beta_{2}>0$ is that when capital and skilled labor are relative complements, industries experiencing a greater increase in capital intensity are those with a larger increase in the non-production worker share of total labor costs.

We estimate eq. (5) as well as a modification that drops the relative wage variable,

\footnotetext{
${ }^{44}$ See Berman, Bound, and Griliches (1994) and Brown and Christensen (1981). The approach is used, as well, by Bartel and Lichtenberg (1987). Our findings are not sensitive to whether we include materials as an additional variable factor of production.
} 
because cross-sectional wage variation could largely reflect skill differences, not exogenous wage variation. ${ }^{45}$ The data are matched at the (pseudo) 4-digit SIC industry level -- there are 256 -for 1909 and 1919, the last year until 1957 that the census of manufactures inquired about the capital stock. Non-production workers were listed in the four groups: proprietors, officers, managers (often including professionals), and clericals (often including other salaried workers), and their share of manufacturing employment increased from $13.9 \%$ in 1909 to $15.7 \%$ in 1919 . Among the data issues we had to confront are the treatment of proprietor earnings and the choice of output and capital deflators. ${ }^{46}$ In some industries (e.g., bakeries), proprietors were a large fraction of all workers and probably performed managerial and clerical duties. We have chosen to exclude their income from the wage bill. ${ }^{47}$ Our input (capital) and output (shipments; value added, viz., shipments minus materials cost) variables are both nominal measures. In the absence of industry-specific output prices and materials and investment deflators, we use the aggregate WPI for the 1909 and 1919 period and, for consistency, the aggregate PPI for finished goods in the 1959 to 1989 comparison period. ${ }^{48}$

The results for 1909 to 1919 , given in Table 6, reveal that the coefficient on the change in

\footnotetext{
${ }^{45}$ Another reason not to include the wage ratio when estimating eq. (5) is that the estimates will then suffer from a version of division bias, because $w_{p}$ appears in the denominators of both the dependent variable and the wage ratio measure. Following Berman, Bound, and Griliches (1994), we also add an output term to account for cyclical differences in the extent to which non-production and production labor are quasi-fixed factors. The inclusion of $d \ln (Q)$ also allows the production function to be non-homothetic.

${ }^{46}$ The weighting of the regression is another data issue. Because classification errors are more of a problem for small industries we weight by the wage bill share. Qualitatively similar results obtain without weights, and median regressions (LAD estimates) without weights also yield similar results.

${ }^{47}$ Two methods of accounting for proprietor earnings can be offered: one imputes their earnings as if they earned the average non-production wage in the census, and the second assumes that proprietor income entirely reflects returns to capital and should not be included in the overall wage bill (it was not supposed to be included). We present the results under the latter assumption; they are robust to either.

${ }^{48}$ We can test the sensitivity of applying industry-specific versus aggregate deflators using the 1959 to 1989 data. We find that the results regarding the capital-skill complementarity coefficient $\left(\beta_{2}\right)$ are robust to the choice of deflator.
} 
the $(\log )$ capital-output ratio $\left(\beta_{2}\right)$ is consistently positive and significant regardless of other controls and independent of the output measure (shipments or value added). ${ }^{49}$ Inclusion of the change in the relative wage reduces the coefficient somewhat, but far less so when we purge the wage differential of certain compositional effects. ${ }^{50}$ We also find that the inclusion of a measure of technological advance -- the change in the percentage of horsepower run by purchased electricity -- does not noticeably affect the coefficient on $d \ln (K / Q)$ and is itself positive.

How large we think the effects in Table 6 are will depend on their magnitude in more recent years when many have concluded on the basis of such regressions that there is capitalskill complementarity. We present such a comparison in Table 7. The first two columns repeat the results from cols. (1) and (2) in Table 6. The remaining six give nearly identical estimations for 1959-69, 1969-79, and 1979-89. The striking finding is that the coefficient on the change in the (log) capital-output ratio $\left(\beta_{2}\right)$ is larger for the $1909-19$ period than more recently. Only one coefficient -- that for 1979-89 in the estimation with the change in shipments variable -- is larger.

The comparison of the results for 1909-19 with those more recently suggests a strong movement during the 1910 s toward capital-skill complementarity. We do not yet know whether the shift toward capital-skill complementarity preceded the 1910s, nor can we discern whether it continued beyond. ${ }^{51}$ But the historical evidence suggests that the 1910 s were a critical moment in the history of American industry when new goods and new processes were introduced as never before. Moreover, the new goods and processes were associated with

\footnotetext{
${ }^{49}$ Qualitatively similar results are obtained by using the employment share of non-production workers as the dependent variable. We prefer the cost share measure because it implicitly adjusts for changes in relative labor quality and hours of work.

${ }^{50}$ To mitigate the influence of compositional effects on changes in the sectoral skill premia, we use the clerical wage for the non-production workers and we adjust the change in the skill premium for changes in percent female and child among production workers (see col. 7 of Table 6).

${ }^{51}$ We might be able to analyze the role of capital before 1909 but not between 1919 and the early 1950 s.
} 
relatively more educated and skilled labor, as we showed above.

\section{Technological Change and Capital-Skill Complementarity: Historical Insights and Conclusion}

The goal of this paper was to locate the origins, and thus the sources, of technology-skill and capital-skill complementarity in manufacturing. We have demonstrated that such relative complementarities existed from 1909 to 1929 and were associated with technologies such as continuous and batch processes and the adoption of electric motors. To motivate the empirical work, we devised a framework in which capital is a relative complement of skilled labor in the creation of workable capital but in which unskilled labor is used with workable capital to create output. Manufacturing-wide capital-skill complementarity can arise from shifts between technologies. Our evidence pertains mainly to the period since 1909 and the transition from the factory to continuous and batch processes and electric motors; we can say little about the earlier transition from artisanal shops to the factory with our data.

A wide variety of innovations dominated the relationships among capital, technology, and skill. We often hear that ours is a time of extraordinary technological change. Yet those that appeared or diffused in the two decades around 1915 may have been more consequential. Manufacturing horsepower in the form of purchased electricity rose from $9 \%$ in 1909 to $53 \%$ in 1929; similar changes swept residential use. New goods proliferated, such as the automobile, airplane, commercial radio, aluminum, synthetic dyes, and rayon; household electric appliances such as the refrigerator and washing machine; office machinery such as calculators, dictating machines, and copying equipment. New techniques enhanced the production of rubber, plate glass, gasoline, canned condensed milk, and factory-made butter. Of the goods mentioned all but the auto are among the higher-education industries in 1940 and which appear to have been the higher-skill industries in the 1910s and 1920s. Looking back at Table 2, the high-education 
industries include: aircraft, office and store machines, petroleum refining, dairy products, electrical machinery, paints and varnishes, miscellaneous machinery, and nonferrous metals.

Input price changes may have been reinforcing in enticing firms to adopt particular technologies. Among the changes in input prices, the decline in the price of purchased electricity was the greatest and perhaps most important. ${ }^{52}$ Cheaper power, purchased electricity, and unit drive meant that firms could adopt different types of capital and production processes. ${ }^{53}$ Although the existence of electric utilities meant that less capital was needed to generate power within firms, production-capital (as opposed to power-generating capital) could run faster and hotter, thereby requiring more skilled workers to maintain it.

Before its sharp curtailment with World War I, the continuing flood of unskilled immigrants must have encouraged the adoption of technologies intensive in unskilled labor and with the decrease in immigration, firms should have pursued an opposite course. We have already noted that industries rapidly automated after 1916, eliminating scores of laborer positions. But it was not just the diminution of immigration that may have altered the direction of innovation and adoption. We have elsewhere demonstrated that high schools diffused rapidly in the United States from 1910 to 1940 and that by the 1920 s a substantial fraction of youths in America had completed several years of secondary schooling (Goldin 1994, Goldin and Katz 1995). The vast majority of those who graduated high school in the 1910 s but did not continue to college, entered a host of ordinary white-collar occupations, such as clerks, bookkeepers, secretaries, and various sales positions. The large premium to high-school educated workers that existed at the turn of the century, and which may have prompted the high school expansion,

\footnotetext{
${ }^{52}$ According to Woolf (1980, table 2.1$)$ nominal price declines for electricity were $3.4 \%$ and real declines exceeded 5\% average annually from 1910 to 1929.

${ }^{53}$ See Du Boff (1964) and Devine (1983) on why electricity diffused slowly throughout industry until the 1920 s and the role of the capital stock and unit drive (i.e., separate motors for each tool).
} 
was markedly reduced by the 1920s, although it remained substantial. A once-expensive commodity -- a high-school graduate -- suddenly became a more reasonably-priced input.

The technologically-forward industries also grew the fastest, not surprisingly. If we define a high-education industry (see Table 2) as one in which more than one-third of the young male blue-collar workers had a high-school degree in 1940, the share of manufacturing employment in these industries rose from $20.7 \%$ in 1909 to $26.7 \%$ in 1929 . The share in loweducation industries (defined as less than $23 \%$ with high school degrees in 1940) declined from $29.0 \%$ in 1909 to $20.5 \%$ in 1929 . The share of manufacturing employment in the top five (2-digit) industries by education (petroleum, chemicals, electrical machinery, printing \& publishing, and scientific instruments) continued to expand from 1910 to 1940 (from 10\% to $16 \%$ ). Similar shifts exist today and reinforce the effects of capital- and technology-skill complementarity.

What did the various changes we detail imply for the wage structure? On the shop-floor and in the office and executive suite the relative demand for skilled and educated labor must have increased greatly from 1910 to $1940 .{ }^{54}$ But we have reported elsewhere that the wage of ordinary white-collar workers fell relative to that for all production workers from the late $1910 \mathrm{~s}$ to the early 1920s with the increase in high schools (Goldin and Katz 1995). It now seems clear that blue-collar employments absorbed some of the increased supply of the high-school educated. The response to increased demand for educated workers was overwhelming: in thousands of school districts across the United States high schools mushroomed, curricula changed, and enrollments soared. The differential between the high-school educated blue or white-collar employee and the less-educated worker may thereby have been kept in check.

${ }^{54}$ Chandler (1977) notes that the managerial revolution was also brought about by many of the technologies we believe increased the relative demand for educated labor on the shop-floor. The denand for more educated workers on the farm must also have increased as farm machinery became more complex. Perhaps that is why high schools expanded even more rapidly in the rural farm areas of the Great Plains and Far West than elsewhere. 


\section{REFERENCES}

Allen, Steven G. 1996. "Technology and the Wage Structure." NBER Working Paper No. 5534 (April).

Anderson, H. Dewey, and Percy E. Davidson. 1940. Occupational Trends in the United States. Stanford, CA: Stanford University Press.

Atack, Jeremy. 1987. "Economies of Scale and Efficiency Gains in the Rise of the Factory in America, 18201900." In P. Kilby, ed., Quantity and Quiddity: Essays in U.S. Economic History. Middletown CT: Wesleyan University Press: 286-335.

Autor, David, Lawrence F. Katz, and Alan Krueger. 1996. "How Computers Are Changing the Labor Market," Working paper in progress.

Bartel, Ann P., and Frank Lichtenberg. 1987. "The Comparative Advantage of Educated Workers in Implementing New Technology," Review of Economics and Statistics 69 (February): 1-11.

Bartel, Ann P., and Nachum Sicherman. 1995. "Technological Change and the Skill Acquisition of Young Workers." NBER Working Paper No. 5107 (May).

Bartelsman, Eric, and Wayne Gray. 1994. "NBER Manufacturing Productivity Database." Unpublished paper, NBER, (December).

Berman, Eli, John Bound, and Zvi Griliches. 1994. "Changes in the Demand for Skilled Labor within U.S. Manufacturing Industries: Evidence from the Annual Survey of Manufacturing," Quarterly Journal of Economics 109 (May): 367-97.

Berndt, Ernst R., Catherine J. Morrison, and Larry S. Rosenblum. 1992. "High-Tech Capital Formation and Labor Composition in U.S. Manufacturing Industries: An Exploratory Analysis." NBER Working Paper No. 4010 (March).

Bound, John, and George Johnson. 1992. "Changes in the Structure of Wages in the 1980s: An Evaluation of Alternative Explanations," American Economic Review 82 (June): 371-92.

Braverman, Harry. 1974. Labor and Monopoly Capital: The Degradation of Work in the Twentieth Century. New York: Monthly Review Press.

Brown, Randall S., and Laurits R. Christensen. 1981. "Estimating Elasticities of Substitution in a Model of Partial Static Equilibrium: An Application to U.S. Agriculture, 1947 to 1974." In E. Berndt and B. Field, eds., Modeling and Measuring Natural Resource Substitution. Cambridge, MA: MIT Press: 209-29.

Cain, Louis P., and Donald G. Paterson. 1986. "Biased Technical Change, Scale, and Factor Substitution in American Industry, 1850-1919," Journal of Economic History 46 (March): 153-64.

Chandler, Alfred D. Jr. 1977. The Visible Hand: The Managerial Revolution in American Business. Cambridge, MA: Belknap Press of Harvard University Press.

Creamer, Daniel, Sergei P. Dobrovolosky, and Israel Borenstein. 1960. Capital in Manufacturing and Mining: Its Formation and Financing. Princeton, NJ: Princeton University Press for the NBER.

Chiswick, Carmel Ullman. 1979. "The Growth of Professional Occupations in U.S. Manufacturing: 1900- 
1973," Research in Human Capital and Development 1: 191-217.

Devine, Warren. 1983. "From Shafts to Wires: Historical Perspective on Electrification," Joumal of Economic History 43 (June): 347-72.

Doms, Mark, Timothy Dunne, and Ken Troske. 1995. "Workers, Wages, and Technology." Unpublished paper, U.S. Bureau of the Census, Center for Economic Studies (September).

Du Boff, Richard. 1964. "Electric Power in American Manufacturing 1889-1958." Ph.D. dissertation, University of Pennsylvania.

Economic Report of the President. 1995. Washington, G.P.O.

Fabricant, Solomon. 1940. The Output of Manufacturing Industries, 1899-1937. Publication No. 39. New York: NBER.

Fallon, P.R., and P.R.G. Layard. 1975. "Capital-Skill Complementarity, Income Distribution, and Output Accounting," Journal of Political Economy 83 (April): 279-301.

Goldin, Claudia. 1994. "How America Graduated from High School: 1910 to 1960." NBER Working Paper No. 4762 (June).

Goldin, Claudia, and Lawrence F. Katz. 1995. "The Decline of Noncompeting Groups: Changes in the Premium to Education, 1890 to 1940." NBER Working Paper No. 5202 (August).

Goldin, Claudia, and Lawrence F. Katz. 1996. "The U.S. Educational Stock and Economic Growth: New Estimates and Their Implications." Working paper in progress.

Griliches, Zvi. 1969. "Capital-Skill Complementarity," Review of Economics and Statistics 51 (November): 46568.

Hamermesh, Daniel S. 1993. Labor Demand. Princeton: Princeton University Press.

Hounshell, David. 1984. From the American System to Mass Production. Baltimore, MD: Johns Hopkins Press.

Inter-university Consortium for Political and Social Research (ICPSR). 1984. Census of Population, 1940 [United States]: Public Use Microdata Sample (ICPSR 8236). Ann Arbor, MI: ICPSR.

James, John A., and Jonathan S. Skinner. 1985. "The Resolution of the Labor-Scarcity Paradox," Journal of Economic History 45 (September): 513-40.

Jerome, Harry. 1934. Mechanization in Industry. New York: National Bureau of Economic Research.

Krueger, Alan. 1993. "How Computers Have Changed the Wage Structure: Evidence from Micro-data, 198489," Quarterly Journal of Economics 108 (February): 33-60.

Landes, David. 1972. The Unbound Prometheus: Technological Change and Industrial Development in Western Europe from 1750 to the Present. Cambridge: Cambridge University Press.

Mincer, Jacob. 1989. "Human Capital Responses to Technological Change in the Labor Market." NBER Working Paper No. 3207 (December). 
Nelson, Daniel. 1987. "Mass Production in the U.S. Tire Industry," Journal of Economic History 47 (June): $329-$ 39.

Nye, David E. 1990. Electrifying America: Social Meanings of a New Technology. Cambridge, MA: MIT Press.

Sokoloff, Kenneth. 1984. "Was the Transition from the Artisanal Shop to the Non-Mechanized Factory Associated with Gains in Efficiency? Evidence from the U.S. Manufacturing Censuses of 1820 and 1850," Explorations in Economic History 21 (October): 351-82.

Sokoloff, Kenneth. 1986. "Productivity Growth in Manufacturing during Early Industrialization." In S. Engerman and R. Gallman, eds., Long-Term Factors in American Economic Growth, Studies in Income and Wealth, NBER, vol. 51. Chicago: University of Chicago Press.

Slichter, Sumner H. 1950. "Notes on the Structure of Wages," Review of Economics and Statistics 32 (February): 80-91.

Tinbergen, Jan. 1975. Income Differences: Recent Research. Amsterdam: North Holland.

U.S. Department of Commerce. Bureau of the Census. 1913. Thirteenth Census of the United States, 1910. vol. VIII. Manufactures, 1909, General Report and Analysis. Washington: G.P.O.

U.S. Department of Commerce. Bureau of the Census. 1923. Fourteenth Census of the United States, 1920. vol. VIII. Manufactures, 1919, General Report and Analytical Tables. Washington: G.P.O.

U.S. Department of Commerce. Bureau of the Census. 1933. Fifteenth Census of the United States, 1930. vol. 1. Manufactures, 1929, General Report. Washington: G.P.O.

U.S. Department of Commerce. Bureau of the Census. 1940. Alphabetic Index of Occupations and Industries: Occupation and Industry Classifications Based on the Respective Standard Classifications, prepared by Alba M. Edwards. Washington: G.P.O.

U.S. Department of Commerce. Bureau of the Census. 1975. Historical Statistics of the United States, from Colonial Times to the Present. Washington: G.P.O.

U.S. Department of Labor. Bureau of Labor Statistics. various years, 1918.-1921 Descriptions of Occupations: Coal and Water Gas, Paint and Varmish, Paper, Printing Trades, Rubber Goods; Electrical Manufacturing Distribution and Maintenance; Glass; Medicinal Manufacturing. Prepared for the U.S. Employment Service. Washington: G.P.O.

Williamson, Jeffrey G., and Peter H. Lindert. 1980. American Inequality: A Macroeconomic History. New York: Academic Press.

Woolf, Arthur George. 1980. "Energy and Technology in American Manufacturing: 1900-1929." Ph.D. dissertation, Department of Economics, University of Wisconsin. 

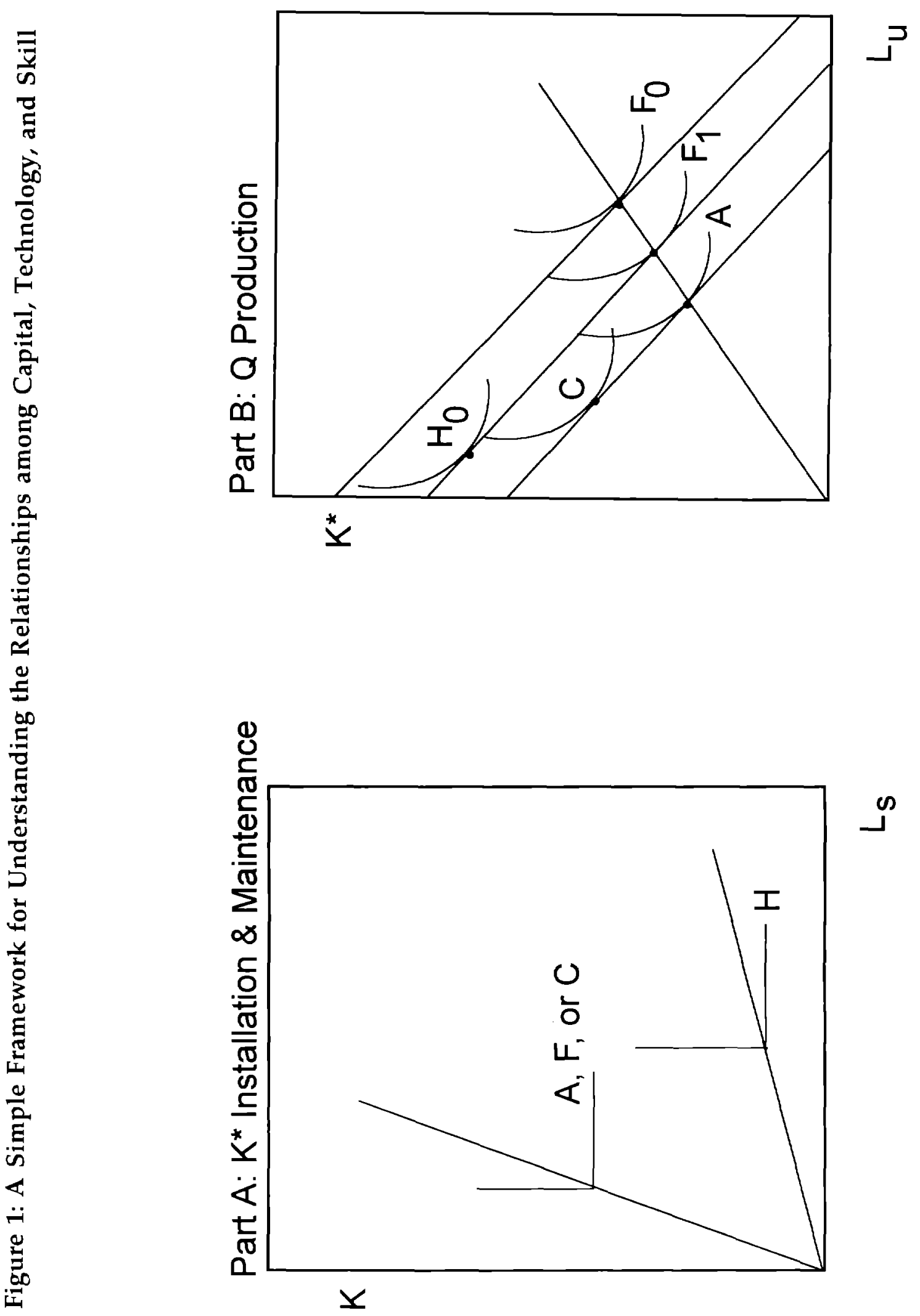
Table 1

Predictions of the Framework

Technological change

\begin{tabular}{|c|c|c|}
\hline $\mathrm{K} / \mathrm{Q}$ & $K /\left(L_{s}+L_{u}\right)$ & $\mathrm{L}_{\mathrm{s}} /\left(\mathrm{L}_{\mathrm{s}}+\mathrm{L}_{\mathrm{u}}\right)$ \\
\hline$\uparrow_{a}$ & $?^{\mathrm{b}}$ & $\downarrow^{c}$ \\
\hline$\downarrow$ & $\rightarrow$ & $\rightarrow$ \\
\hline$\uparrow$ & $\uparrow$ & $\uparrow$ \\
\hline
\end{tabular}

(c) Shift from assembly-line (A) to continuous process (or batch) methods (C)

(a) Shift from artisanal or hand trades $(\mathrm{H})$ to factory production $(F)$

(b) Shift from factory (F) to assembly-line (A) production (Hicks-neutral technical change)

\section{)}

Notes:

$\mathrm{K}$ = capital stock

$\mathrm{L}_{\mathrm{s}}=$ skilled or more-educated labor

$\mathrm{L}_{\mathrm{u}}=$ unskilled or less-educated labor
${ }^{a}$ The prediction is obtained when: $\left(\lambda_{\mathrm{F}}{ }^{k} / \lambda_{\mathrm{H}}{ }^{k}\right)<\left[\left(1-\alpha_{\mathrm{F}}\right) /\left(1-\alpha_{\mathrm{H}}\right)\right] \cdot\left(\mathrm{r}_{\mathrm{H}}^{*} / \mathrm{r}_{\mathrm{F}}^{*}\right)$. That is, considering the restrictive case discussed in the text of equal $r^{*}$ for $H$ and $F$, the prediction is correct only if the higher $\mathrm{K}^{*}$-intensity for the $\mathrm{H}$ technology is outweighed by the greater use of $\mathrm{K}$ in the creation of $\mathrm{K}^{*}$ in the $\mathrm{F}$ technology.

${ }^{\mathbf{b}}$ The impact of (a) on $\left[K /\left(\mathrm{L}_{s}+\mathrm{L}_{\mathrm{u}}\right)\right]$ is ambiguous in the case when $\left[\mathrm{L}_{s} /\left(\mathrm{L}_{\mathrm{s}}+\mathrm{L}_{u}\right)\right]$ declines.

c The prediction holds in the restrictive case of equal $r^{*}$ for $\mathrm{H}$ and $\mathrm{F}$. When the $\mathrm{r}^{*}$ differ, the condition is: $\left(\mathrm{r}_{\mathrm{H}}^{*} / \mathrm{r}_{\mathrm{F}}^{*}\right)<\left[\left(\alpha_{\mathrm{F}} / \alpha_{\mathrm{H}}\right)\right] \cdot\left[\left(1-\alpha_{\mathrm{H}}\right) /\left(1-\alpha_{\mathrm{F}}\right)\right] \cdot\left(\lambda_{\mathrm{F}}^{1} / \lambda_{\mathrm{H}}^{1}\right)$. 
Table 2

Percentage High School Graduates by Industry, 18 to 34-Year Old Male Blue-Collar Workers: 1940

\begin{tabular}{|c|c|c|c|c|c|}
\hline $\begin{array}{l}\text { 2-Digit SIC Manufacturing } \\
\text { Industries }\end{array}$ & $\begin{array}{l}\% \text { H.S. } \\
\text { Grad. }\end{array}$ & $\begin{array}{l}\text { Number } \\
\text { of Obs. }\end{array}$ & $\begin{array}{l}\text { 2-Digit SIC Manufacturing } \\
\text { Industries }\end{array}$ & $\begin{array}{l}\text { \% H.S. } \\
\text { Grad. }\end{array}$ & $\begin{array}{l}\text { Number } \\
\text { of Obs. }\end{array}$ \\
\hline \multicolumn{3}{|c|}{$\begin{array}{l}\text { High-education industries (from high to low) } \\
\text { Top } 20 \% \text { by employment }\end{array}$} & \multicolumn{3}{|c|}{$\begin{array}{l}\text { Low-education industries (from low to high) } \\
\text { Bottom } 20 \% \text { by employment }\end{array}$} \\
\hline Aircraft and parts & 52.4 & 540 & Cotton manufactures & 10.7 & 1510 \\
\hline Printing and publishing & 44.7 & 1287 & Logging & 11.2 & 705 \\
\hline Office machinery & 43.4 & 166 & Tobacco & 11.8 & 144 \\
\hline Petroleum refining & 43.2 & 414 & Sawmills and planing mills & 13.8 & 1940 \\
\hline Dairy products & 42.9 & 417 & Not specified textile mills & 15.6 & 128 \\
\hline $\begin{array}{l}\text { Scientific and photographic } \\
\text { equipment }\end{array}$ & 40.5 & 227 & Silk and rayon manufactures & 16.3 & 349 \\
\hline Electrical machinery & 40.3 & 976 & Carpets and rugs & 16.8 & 107 \\
\hline Misc. nonmetallic mineral products & 35.6 & 135 & Cut-stone and stone products & 16.8 & 101 \\
\hline Paints and varnishes & 35.5 & 107 & Misc. fabricated textiles & 17.0 & 94 \\
\hline Ship building & 34.0 & 526 & Misc. textile goods & 17.1 & 117 \\
\hline Clocks, watches, jewelry & 34.0 & 197 & Structural clay products & 18.8 & 271 \\
\hline Misc. machinery & 33.4 & 1669 & $\begin{array}{l}\text { Cement and concrete, gypsum, } \\
\text { and plaster products }\end{array}$ & 19.4 & 263 \\
\hline \multirow[t]{4}{*}{ Nonferrous metals } & 32.6 & 341 & Hats, except cloth and millinery & 20.0 & 60 \\
\hline & & & Dyeing and finishing textiles & 20.4 & 191 \\
\hline & & & Misc. wooden goods & 21.5 & 474 \\
\hline & & & $\begin{array}{l}\text { Footwear industries except } \\
\text { rubber }\end{array}$ & 22.8 & 680 \\
\hline
\end{tabular}

Notes: The sample is limited to 18 to 34 -year old, currently-employed males in blue-collar occupations (craft, operative, laborer, service) in manufacturing. The mean for the entire sample of 31,500 is $27.4 \%$. The industry names are those given in ICPSR (1984). The $20 \%$ figure used as the cutoff is for all workers, not just male blue-collar workers $18-34$ years old.

Source: 1940 Public Use Micro-data Sample, 1/100; ICPSR (1984). 
Table 3

Education, Capital Intensity, and Electricity Usage, 1909 and 1919

\begin{tabular}{|c|c|c|c|c|}
\hline & \multicolumn{4}{|c|}{$\begin{array}{c}\text { Fraction High School Graduates among } 18 \text { to } 34 \text {-Year Old Males in } \\
\text { Blue-Collar Occupations, by Industry }\end{array}$} \\
\hline & \multicolumn{2}{|c|}{ Capital Intensity } & \multicolumn{2}{|c|}{ Capital and Electrification } \\
\hline & $(1)$ & (2) & (3) & $(4)$ \\
\hline & 1909 & 1919 & 1919 & 1919 \\
\hline \multirow[t]{2}{*}{$\log (K / L)$} & .0556 & .0537 & .0578 & .0517 \\
\hline & $(.0191)$ & $(.0226)$ & $(.0218)$ & $(.0228)$ \\
\hline \multirow[t]{2}{*}{$\%$ hp purchased electricity } & & & .206 & \\
\hline & & & $(.0597)$ & \\
\hline \multirow[t]{2}{*}{$\log ($ hp purchased electricity/L) } & & & & .0397 \\
\hline & & & & $(.0168)$ \\
\hline \multirow[t]{2}{*}{$\log ($ other horsepower/L) } & & & & -.0431 \\
\hline & & & & $(.0098)$ \\
\hline \multirow[t]{2}{*}{$\log ($ total horsepower/L) } & & & -.0058 & \\
\hline & & & $(.0167)$ & \\
\hline \multirow{2}{*}{ d log(employment $)_{1909,1929}$} & & & .0391 & .0380 \\
\hline & & & $(.0141)$ & $(.0143)$ \\
\hline \multirow[t]{2}{*}{$\%$ artisan } & .202 & .204 & .129 & .132 \\
\hline & $(.0377)$ & $(.0396)$ & $(.0332)$ & $(.0328)$ \\
\hline \multirow[t]{2}{*}{$\%$ female } & .109 & .0610 & -.0464 & -.0249 \\
\hline & $(.0605)$ & $(.0584)$ & $(.0713)$ & $(.0726)$ \\
\hline \multirow[t]{2}{*}{$\%$ children } & -2.00 & -1.99 & -1.02 & -1.20 \\
\hline & $(.551)$ & $(.574)$ & $(.520)$ & $(.542)$ \\
\hline \multirow[t]{2}{*}{ Constant } & .215 & .211 & .106 & .203 \\
\hline & $(.0268)$ & $(.0403)$ & $(.0412)$ & $(.0342)$ \\
\hline Number of observations & 57 & 57 & 57 & 57 \\
\hline $\mathrm{R}^{2}$ & .495 & .452 & .719 & .716 \\
\hline
\end{tabular}

Notes: The unit of observation is a 1940-industry group. Industries from the 1909, 1919, and 1929 Censuses of Manufactures are aggregated up to the 1940 groupings, e.g., beverages in 1940 contains the 1909 categories of distilled, malt, and vinous liquors, and mineral and soda waters. Each observation is weighted by the industry share of total blue-collar employment in manufacturing averaged over 1909, 1919, and 1929. The dependent variable is the percentage of 18 to 34-year old, male blue-collar workers in the industry in 1940 who graduated high school. The mean for 1940 among all blue-collar workers in this group is 0.274 . Standard errors are in parentheses. 
$\log (\mathrm{K} / \mathrm{L})=\log$ of capital stock (000, in current dollars) per wage earner in each industry for 1909 and 1919 respectively, as indicated by the column headings;

$\%$ hp purchased electricity = fraction total horsepower run by purchased electricity, averaged over 1909, 1919, and 1929;

$\log ($ hp purchased electricity/L) $=\log$ of horsepower run by purchased electricity per wage earner averaged over 1909, 1919, and 1929;

$\log ($ other horsepower $/ \mathrm{L})=\log$ of total horsepower minus horsepower run by purchased electricity per wage earner averaged over 1909, 1919, and 1929;

$\log ($ total horsepower $/ L)=\log$ of total horsepower per wage earner averaged over 1909, 1919, and 1929; d log(employment $)_{1909,1929}=$ change in log of total employment from 1909 to 1929;

$\%$ artisan = fraction of wage earners in the 1940 industry categories who were in an artisanal trade averaged over 1909, 1919, and 1929. Artisan is defined as working in: gold and silver, leaf \& foil; jewelry; photo-engraving; stereotyping \& electrotyping; cardcut design; wood \& die engraving; glass; glass-cutting, staining \& ornamenting; instruments; optical goods; statuary art. Printing \& publishing is also included because of its special feature of demanding a literate labor force;

$\%$ female = average fraction of wage earners female in 1909, 1919, and 1929;

$\%$ child = average fraction of wage earners child in 1909 and 1919;

Sources: U.S. Department of Commerce, Bureau of the Census (1913, 1923, 1933) supplemented with data provided by Arthur Woolf. See Woolf (1980).

1940 Public-Use Microdata Sample, 1/100; ICPSR (1984). 
Table 4

Relationship between Earnings $(1909,1919,1929)$ and Education (1940)

for 18 to 34-Year Old Blue-Collar Males, by Industry

\begin{tabular}{|c|c|c|c|}
\hline & \multicolumn{3}{|c|}{$\begin{array}{l}\text { Log (Average Annual, Current } \$, \text { Wage) } \\
\quad \text { in } 1909,1919, \text { or } 1929 \text { Industry }\end{array}$} \\
\hline & 1909 & 1919 & 1929 \\
\hline $\begin{array}{l}\text { Average years schooling among blue-collar, } \\
18 \text { to } 34 \text {-year old males in } 1940 \text { industry } \\
\text { grouping }\end{array}$ & $\begin{array}{c}.124 \\
(.0111)\end{array}$ & $\begin{array}{c}.0984 \\
(.0123)\end{array}$ & $\begin{array}{c}.175 \\
(.0192)\end{array}$ \\
\hline $\begin{array}{l}\text { Percentage (females }+ \text { children) among wage } \\
\text { earners in } 1909 \text { or } 1919 \text { industry; percentage } \\
\text { female in } 1929 \text { industry }\end{array}$ & $\begin{array}{c}-.495 \\
(.0681)\end{array}$ & $\begin{array}{l}-.605 \\
(.110)\end{array}$ & $\begin{array}{c}-.497 \\
(.0918)\end{array}$ \\
\hline Constant & $\begin{array}{c}5.22 \\
(.102)\end{array}$ & $\begin{array}{c}6.25 \\
(.109)\end{array}$ & $\begin{array}{c}5.65 \\
(.185)\end{array}$ \\
\hline Number of observations & 191 & 191 & 191 \\
\hline Mean of weighted dependent variable & 6.22 & 7.02 & 7.14 \\
\hline $\mathrm{R}^{2}$ & .698 & .643 & .656 \\
\hline$\hat{\sigma}$ & .117 & .133 & .151 \\
\hline
\end{tabular}

Notes: The number of 1940 industries is less than the number of 1909, 1919, or 1929 industries. Regressions are weighted by the number of wage-earners in each 1909, 1919, 1929 industry. Numbers in parentheses are Huber (White) standard errors allowing for grouped errors within 1940 industries. The education variable (average number of years of school) is from the 1940 PUMS. The average wage is computed as the wage bill/(average annual number of wage earners) for all years.

Source: U.S. Department of Commerce, Bureau of the Census $(1913,1923,1933)$ supplemented with data provided by Arthur Woolf. See Woolf (1980).

1940 Public Use Micro-data Sample, 1/100; ICPSR (1984). 
Table 5

Relationship between Production-Worker Earnings and Industry Characteristics, 1909, 1919, 1929

\begin{tabular}{|c|c|c|c|c|}
\hline & \multicolumn{4}{|c|}{$\begin{array}{l}\text { Log (Average Annual, Current } \$ \text {, Wage) } \\
\text { in } 1909,1919, \text { or } 1929 \text { Industry }\end{array}$} \\
\hline & $\begin{array}{l}1909 \\
\text { (s.e.) }\end{array}$ & $\begin{array}{l}1919 \\
\text { (s.e.) }\end{array}$ & $\begin{array}{l}1929 \\
\text { (s.e.) }\end{array}$ & $\begin{array}{l}\text { Means, } 1929 \\
\text { (s.d.) }\end{array}$ \\
\hline $\log (K / L)$ & $\begin{array}{l}.0910 \\
(.0151)\end{array}$ & $\begin{array}{c}.0417 \\
(.0169)\end{array}$ & $\begin{array}{c}.0480 \\
(.0262)\end{array}$ & $\begin{array}{c}1.44 \\
(.510)\end{array}$ \\
\hline$\%$ hp purchased electricity & $\begin{array}{c}.439 \\
(.0556)\end{array}$ & $\begin{array}{c}.266 \\
(.0374)\end{array}$ & $\begin{array}{c}.546 \\
(.0548)\end{array}$ & $\begin{array}{l}.637 \\
(.211)\end{array}$ \\
\hline $\log ($ total horsepower/L) & $\begin{array}{l}-.0213 \\
(.0115)\end{array}$ & $\begin{array}{r}-.00149 \\
(.0131)\end{array}$ & $\begin{array}{c}.0184 \\
(.0189)\end{array}$ & $\begin{array}{r}1.09 \\
(1.07)\end{array}$ \\
\hline $\log$ (establishment size) & $\begin{array}{c}.0622 \\
(.00633)\end{array}$ & $\begin{array}{c}.0780 \\
(.00577)\end{array}$ & $\begin{array}{c}.0638 \\
(.0103)\end{array}$ & $\begin{array}{c}4.51 \\
(1.08)\end{array}$ \\
\hline$\%$ female & $\begin{array}{c}-.427 \\
(.0563)\end{array}$ & $\begin{array}{c}-.308 \\
(.0613)\end{array}$ & $\begin{array}{c}-.307 \\
(.0881)\end{array}$ & $\begin{array}{c}.210 \\
(.225)\end{array}$ \\
\hline$\%$ child & $\begin{array}{l}-3.41 \\
(.377)\end{array}$ & $\begin{array}{l}-6.91 \\
(.697)\end{array}$ & $\begin{array}{l}-6.41 \\
(.927)\end{array}$ & $\begin{array}{c}.014 \\
(.016)\end{array}$ \\
\hline Artisan & $\begin{array}{c}.136 \\
(.0338)\end{array}$ & $\begin{array}{c}.144 \\
(.0336)\end{array}$ & $\begin{array}{c}.273 \\
(.0481)\end{array}$ & $\begin{array}{l}.0563 \\
(.231)\end{array}$ \\
\hline Constant & $\begin{array}{c}5.99 \\
(.0306)\end{array}$ & $\begin{array}{c}6.65 \\
(.0386)\end{array}$ & $\begin{array}{c}6.56 \\
(.0666)\end{array}$ & \\
\hline Number of observations & 228 & 225 & 228 & \\
\hline Mean of weighted dependent variable & 6.23 & 7.03 & 7.15 & \\
\hline $\mathrm{R}^{2}$ & .791 & .813 & .667 & \\
\hline$\hat{\sigma}$ & .0991 & .0973 & .148 & \\
\hline
\end{tabular}

Notes: The average wage is computed as the (production-worker wage bill)/(average annual number of wage earners) for all years. Independent variables are defined in Table 3. $\log (\mathrm{K} / \mathrm{L})$ by industry for 1919 is used in the 1929 regression; \% child for 1919 is used in the 1929 regression. Regressions are weighted by the number of wage earners in each year, as are the means for 1929.

Source: U.S. Department of Commerce, Bureau of the Census $(1913,1923,1933)$ supplemented with data provided by Arthur Woolf. See Woolf (1980). 
Table 6

Change in the Nonproduction-Worker Share of Wage Bill, 1909 to 1919

\begin{tabular}{|c|c|c|c|c|c|c|c|c|}
\hline Variable & (1) & (2) & (3) & (4) & (5) & (6) & (7) & (8) \\
\hline $\mathrm{d} \ln (\mathrm{K} / \mathrm{Q})$ & $\begin{array}{c}.059 \\
(.011)\end{array}$ & $\begin{array}{c}.051 \\
(.012)\end{array}$ & & & $\begin{array}{c}.044 \\
(.010)\end{array}$ & & $\begin{array}{c}.054 \\
(.010)\end{array}$ & $\begin{array}{c}.048 \\
(.012)\end{array}$ \\
\hline$d \ln (Q)$ & & $\begin{array}{l}-.008 \\
(.004)\end{array}$ & & & & & & $\begin{array}{l}-.013 \\
(.005)\end{array}$ \\
\hline $\mathrm{d} \ln (\mathrm{K} / \mathrm{VA})$ & & & $\begin{array}{c}.051 \\
(.010)\end{array}$ & $\begin{array}{c}.042 \\
(.011)\end{array}$ & & $\begin{array}{c}.032 \\
(.010)\end{array}$ & & \\
\hline $\mathrm{d} \ln (\mathrm{VA})$ & & & & $\begin{array}{l}-.0080 \\
(.0044)\end{array}$ & & & & \\
\hline $\operatorname{dln}\left(w_{n} / w_{p}\right)$ & & & & & $\begin{array}{c}.094 \\
(.013)\end{array}$ & $\begin{array}{c}.092 \\
(.014)\end{array}$ & & \\
\hline $\mathrm{d} \ln \left(\mathrm{w}_{\mathrm{c}} / \mathrm{w}_{\mathrm{p}}\right)$ & & & & & & & $\begin{array}{c}.099 \\
(.014)\end{array}$ & \\
\hline $\mathrm{d}(\%$ elec. $)$ & & & & & & & & $\begin{array}{c}.046 \\
(.020)\end{array}$ \\
\hline Constant & $\begin{array}{c}.017 \\
(.003)\end{array}$ & $\begin{array}{c}.018 \\
(.003)\end{array}$ & $\begin{array}{c}.016 \\
(.003)\end{array}$ & $\begin{array}{c}.017 \\
(.003)\end{array}$ & $\begin{array}{c}.034 \\
(.004)\end{array}$ & $\begin{array}{c}.032 \\
(.004)\end{array}$ & $\begin{array}{c}.016 \\
(.003)\end{array}$ & $\begin{array}{c}.008 \\
(.005)\end{array}$ \\
\hline $\mathbf{R}^{2}$ & .100 & .111 & .093 & .105 & .248 & .227 & .247 & .108 \\
\hline$\hat{\sigma}$ & .0367 & .0366 & .0368 & .0366 & .0336 & .0340 & .0336 & .0357 \\
\hline
\end{tabular}

Notes: The dependent variable is the log change in the nonproduction-worker share of the wage bill between 1909 and 1919. The number of observations is 256 for cols. (1)-(7) and 253 for col. (8). An observation is an industry, generally at the (pseudo for 1909 and 1919) 4-digit SIC level. Regressions are weighted by the average wage bill share between 1909 and 1919. Standard errors are in parentheses. The weighted mean of the dependent variable is 0.006 .

$\mathrm{K}=$ capital stock

$\mathrm{Q}=$ shipments

$\mathrm{VA}=$ value added

$\mathrm{w}_{\mathrm{n}}=$ average wage of non-production workers

$w_{p}=$ average wage of production workers

$w_{\mathrm{c}}=$ average wage of clerical workers

$\mathrm{d} \ln \left(\mathrm{w}_{\mathrm{c}} / \mathrm{w}_{\mathrm{p}}\right)=$ change in the $(\log )$ wage of clerical and productive workers adjusted for the change in the percentage female and percentage child workers of production workers

$\mathrm{d}(\%$ elec. $)=$ change in the fraction of total horsepower run by purchased electricity

Sources: U.S. Department of Commerce, Bureau of the Census $(1913,1923)$. 
Table 7

Change in Nonproduction-Worker Share of Wage Bill:

$1909-19,1959-69,1969-79,1979-89$

\begin{tabular}{|c|c|c|c|c|c|c|c|c|}
\hline \multirow[b]{2}{*}{ Variable } & \multicolumn{2}{|c|}{$1909-19$} & \multicolumn{2}{|c|}{$1959-69$} & \multicolumn{2}{|c|}{$1969-79$} & \multicolumn{2}{|c|}{$1979-89$} \\
\hline & (1) & (2) & (3) & (4) & (5) & (6) & (7) & (8) \\
\hline \multirow[t]{2}{*}{$\mathrm{d} \ln (\mathrm{K} / \mathrm{Q})$} & .059 & .051 & .005 & .018 & .023 & .040 & .024 & .061 \\
\hline & $(.011)$ & $(.012)$ & $(.005)$ & $(.006)$ & $(.006)$ & $(.009)$ & $(.008)$ & $(.011)$ \\
\hline \multirow[t]{2}{*}{$\mathrm{d} \ln (Q)$} & & -.008 & & .026 & & .021 & & .036 \\
\hline & & $(.004)$ & & $(.006)$ & & $(.008)$ & & $(.007)$ \\
\hline \multirow[t]{2}{*}{ Constant } & .017 & .018 & .010 & -.003 & .010 & .005 & .037 & .030 \\
\hline & $(.003)$ & $(.003)$ & $(.002)$ & $(.004)$ & $(.002)$ & $(.003)$ & $(.002)$ & $(.002)$ \\
\hline $\mathrm{R}^{2}$ & .100 & .111 & .002 & .040 & .026 & .040 & .018 & .071 \\
\hline$\hat{\sigma}$ & .0367 & .0366 & .0354 & .0348 & .0415 & .0412 & .0438 & .0427 \\
\hline $\begin{array}{l}\text { Number of } \\
\text { observations }\end{array}$ & 256 & 256 & 450 & 450 & 450 & 450 & 450 & 450 \\
\hline $\begin{array}{l}\text { Mean of weighted } \\
\text { dependent variable }\end{array}$ & .006 & .006 & .011 & .011 & .013 & .013 & .037 & .037 \\
\hline
\end{tabular}

Notes: The dependent variable is the log change in the nonproduction-worker share of the wage bill between the years given. An observation is an industry, generally at the (pseudo) 4-digit SIC level. Regressions are weighted by the average wage bill share between the years given. Standard errors are in parentheses. $d \ln (Q)$ is deflated by the WPI for 1909-19 and by the PPI for finished goods in the other three periods.

$\mathrm{K}=$ capital stock

$\mathrm{Q}=$ shipments

Sources: U.S. Department of Commerce, Bureau of the Census $(1913,1923)$.

NBER Manufacturing Productivity Database, Annual Survey of Manufactures, as described in Bartelsman and Gray (1994).

Deflators. 1909, 1919: U.S. Department of Commerce, Bureau of the Census (1975), series E-40.

All other years: Economic Report of the President (1995), table B-64, p. 347. 